УдК 378.147:656.61

DOI https://doi.org/10.32840/1992-5786.2020.70-4.7

\title{
A. 3. Шайхатдінов
}

кандидат історичних наук, доцент, завідувач кафредри «Природничо-наукові і гуманітарні дисципліни»

Азовського морського інституту Національного університету «Одеська морська академія»

Т. Г. Добіна

кандидат культурології, доцент кафедри соціології та соціальної роботи ДВНЗ «Приазовський державний технічний університет»

\section{РОЛЬ ЕТИКО-РЕЛІГІЙНОЇ ТОЛЕРАНТНОСТІ У ФОРМУВАННІ ПРОФЕСІЙНИХ КОМПЕТЕНТНОСТЕЙ МАЙБУТНІХ СПЕЦІАЛІСТІВ МОРСЬКОГО ТА РІЧКОВОГО ТРАНСПОРТУ}

Статтю присвячено дослідженню ролі етико-релігійної толерантності у формуванні профресійних компетентностей майбутніх спеціалістів морського та річкового транспорту. Розглянуто теоретичні засади етико-релігійної толерантності та багатоаспектність терміна «толерантність». Проаналізовано наявні типи толерантності та базові принципи толерантності згідно з декларацією принципів толерантності, затвердженою Генеральною конференцією ООН. Толерантність це єдність у різноманітті. Толерантність - не тільки моральний обов'язок, а й політична та правова потреба. Толерантність - це те, що уможливлює досягнення миру, сприяє переходу від війни до культури миру.

Оновлення змісту української вищої освіти актуалізує завдання розвитку толерантності як показника деонтологічної компетентності майбутнього спеціаліста морського та річкового транспорту. Досліджено, що Конвенція ПДНВ містить компетентниії, які передбачають високий рівень толерантності до всіх членів екіпажу. Наприклад, компетенції, що стосуються вміння працювати в команді, лідерства та мистецтва управління. Сьогодні українські моряки у складі екіпажів морських вантажних, пасажирських, рибальських та інших типів торгових суден працюють в усьому світі. Оскільки ці судна мають багатонаціональні змішані екіпажі, то без належного рівня як технічної підготовки, так і толерантності до інших працювати неможливо. Під час дослідження було виявлено, що компетенції для спеціалістів морського та річкового транспорту постійно доповнюються та підвищуються. У результаті дослідження запропоновано додати в перелік загальних або спеціальних в освітні стандарти спеціальності такі компетенції: здатність до соціальної толерантності в багатонаціональному екіпажі та здатність правильно і адекватно реагувати на релігійні чи міжособистісні конфрлікти, що виникають під час роботи в змішаних екіпажах на суднах під іноземним прапором.

Ключові слова: етико-релігійна толерантність, профресійні компетентності, морська галузь, Кодекс та Конвенція ПДНВ, декларація принципів толерантності, психологічна адаптація моряків.

Постановка проблеми. Одним із соціальних феноменів сучасного суспільства виступає полікультурність середовища, в якому толерантність $€$ умовою фрормування молодих спеціалістів, оскільки саме від молоді в кризовому суспільстві залежить виживання людства у найближчому майбутньому. Це стосується всіх сфер життя людини: економічної, політичної, соціальної та інших.

Морська галузь, зокрема ринок морських перевезень, теж стає більш мультикультурною та інтернаціональною. Сьогодні значна кількість фахівців здійснює свою профресійну діяльність у професійних спільнотах і колективах із притаманними для окремих членів спільнот релігійними, етич- ними, побутовими звичками та вподобаннями. У зв'язку з цим однією з основних умов успішного виконання своїх профресійних обов'язків $€$ створення та підтримка сприятливого психологічного клімату в колективах. А це можливо за наявності таких якостей, як взаєморозуміння, терпимість, здатність до компромісу, повага до думок, переконань, морально-етичних установок і релігійних обмежень кожного члена колективу. Відсутність взаєморозуміння в колективі та нехтування цими якостями призведе не лише до створення напружених міжособистісних відносин у команді, а й до зниження продуктивності праці через нехтування ініціатив і вимог членів колективу, що, на думку 
інших, $є$ не такими, як усі. В особливо тяжких випадках це може призвести взагалі до кримінальних злочинів, спрямованих проти членів колективу, що вирізняються своїми морально-етичними вподобаннями від інших членів спільноти.

Аналіз останніх досліджень і публікацій. На методичному рівні проблема формування професійної компетентності досліджувалася С. Бондарем, А. Бремусом, О. Гулай, О. Гуренковою, Е. Зеєром, А. Марковою, М. Орловою, Г. Селевко, С. Сисоєвою, І. Тараненко, В. Шарко та іншими вченими.

Зміст поняття толерантності та ії значення у процесі виховання молодих спеціалістів розглядали Л. Вишневська, С. Литвинова, А. Скок, І. Бех та інші. На важливість формування та розвитку етико-релігійної толерантності у студентської молоді вказували Г. Солдатова, О. Кихтюк, В. Тишков, О. Грива, Л. Шайгерова та інші.

Питання процесу формування профресійних якостей майбутніх моряків розглядали у своїх роботах М. Бабишена, О. Безбаха, Т. Зайцева, В. Онищук, М. Кулакова, І. Сокол, М. Шерман та інші.

Мета статті - проаналізувати теоретичні засади та роль етико-релігійної толерантності у фрормуванні професійних компетентностей майбутніх спеціалістів річкового та морського транспорту.

Виклад основного матеріалу. Оскільки Україна активно долучається до європейського освітнього та культурного простору, особливого значення набуває професійна підготовка молодих фрахівців, зокрема, в галузі морського та річкового транспорту. Необхідність підвищення рівня професійної компетентності майбутніх робітників морського транспорту визначено вимогами Міжнародної конвенції про підготовку та дипломування моряків і несення вахти (далі - Конвенції ПДНВ, International Convention on Standards of Training Certification and Watchkeeping for Seafarers), в якій зазначено перелік компетентностей і знань, якими повинні володіти майбутні робітники морської галузі для виконання складних операцій в екстремальних умовах, і передбачена підготовленість слухачів до фрізичних, моральних і психологічних навантажень, що зумовлює необхідність фрормування у процесі навчання профе-сійно важливих якостей [1].

Більшість фрахівців морського та річкового транспорту після завершення навчання будуть працювати на суднах у світовому морському просторі та в багатонаціональних екіпажах, тому толерантність спеціаліста буде розглядатися поряд з його професійними навичками. Розглянемо детальніше, що ж таке толерантність, якою має бути толерантна людина та зокрема фрахівець річкового та морського транспорту.

Термін «толерантність» зазвичай вживається в ідеології та політиці, у сфрерах міжетнічних, між- конфесійних, міжпартійних стосунків - узагалі будь-яких стосунків між «ми» і «вони», «свої» та «інші», «чужі». Він позначає характер ставлення до чогось або когось «іншого», якого не можна просто усунути, «нейтралізувати». До останнього часу інваріант різноманітних значень толерантності традиційно схоплюється поняттям терпимості, що походить від дієслова «терпіти» стійко та покірливо витримувати фізичні і моральні страждання або навіть ставати нечутливим, завмирати у відповідь на вплив ззовні [2].

Проблема толерантності вперше виникла в західній цивілізації в релігійній сфрері, а релігійна толерантність поклала початок усім іншим свободам, які були досягнуті в демократичному суспільстві. Ідея толерантності має давню історію. Духовне розкріпачення особи поряд з її економічною та політичною свободою відстоювали мислителі минулого, спираючись на вчення про природне право. Про толерантність у своїх працях «Нариси про терпимість», «Листи про віротерпимість» писав Дж. Лок, у «Трактаті про віротерпимість» до розгляду цієї категорії звертався Вольтер. І. Гьоте розглядав толерантність як проміжний елемент на шляху до визнання, філософр-соціолог [3].

Базові принципи етнічної толерантності закладено в декларації принципів толерантності, що затверджена в листопаді 1995 року Генеральної конфреренцією ООН. Головне, що визначено в цьому документі: поняття толерантності означає повагу, прийняття й правильне розуміння багатоманітності культур нашого світу, форм самовираження й прояву людської індивідуальності. У першій статті декларації стверджується: «Формуванню толерантності сприяють знання, відкритість, спілкування та свобода думки, совісті й переконань. Толерантність - це єдність у різноманітті. Толерантність - не тільки моральний обов'язок, а й політична та правова потреба. Толерантність - це те, що уможливлює досягнення миру, сприяє переходу від війни до культури миру. Толерантність - це не поступка, поблажливість чи потурання. Толерантність - це передусім активна позиція, що формується на основі визнання універсальних прав та основних свобод людини».

Поняття «толерантність» особливо активно почало використовуватися у зв'язку з намаганнями світової спільноти, насамперед таких організацій, як ООН, ЮНЕСКО, врегулювати міжнародні відносини. У науковій літературі толерантність розглядається як повага і визнання рівності, відмова від домінування і насилля, визнання багатомірності людської культури, норм поведінки, відмова від зведення цієї різноманітності до однорідності або домінування якоїсь однієї позиції [4].

Поняття толерантність дуже багатоаспектне. Виховання толерантної людини передбачає не 
лише навчитися стримувати свою неприязнь до іншої людини. Толерантна людина підказує конструктивний вихід із конфліктних ситуацій, орієнтує стосунки на збереження рівноправності, поваги, свободи. Вона забезпечує передачу досвіду позитивної соціальної взаємодії та досвіду людства загалом, забезпечує збереження і примноження культурного досвіду етносу, забезпечує гармонійне мирне співіснування представників, які відрізняються один від одного за різними ознаками; служить суспільним гарантом недоторканності і ненасильства щодо різного роду меншин, служить основою для нормалізації психологічної атмосфери в суспільстві. Лише за умови дотримання поваги до всіх етично-релігійних аспектів можливий подальший розвиток країни та її населення, бо лише щасливі люди можуть нести за собою зміни на краще.

У контексті нашого дослідження можна виділити такі типи толерантності:

1) за спрямованістю:

- зовнішня толерантність (до інших) - сформоване переконання, яке дає можливість особистості припускати наявність в інших власної позиції; наявність здатності розглядати конфліктну ситуацію з різних поглядів, ураховувати різні аспекти та аргументи;

- внутрішня толерантність (внутрішня стійкість) - здатність зберігати рівновагу у різних несподіваних ситуаціях: конфлікт, невизначеність, ризик, стрес; приймати рішення і діяти в цих умовах, навіть якщо невідомі всі фракти й можливі наслідки [5];

2) за розвитком толерантності в особистості:

- природна толерантність - передбачає відкритість, допитливість, довірливість (вона властива маленькій дитині і не асоціюється з якостями іï «Я», оскільки процес становлення особистості ще не привів до розподілу індивідуального і соціального досвіду);

- моральна толерантність - означає терпимість, що асоціюється з особистістю (зовнішнім «Я» людини) (притаманна більшості дорослих людей та проявляється в бажанні стримувати емоції, використовуючи механізми психологічного захисту, тобто людина лише зовні не проявляє нетерпимість, яка залишається у неї усередині);

- етична толерантність - передбачає сприйняття й довіру, що асоціюються із сутністю або внутрішнім «Я» людини (вона включає як повагу до цінностей інших, так і сприйняття власного внутрішнього світу, що надає особистості перевагу не боятися й витримувати напругу та конфрлікти) [5].

Необхідність розв'язання у ВНЗ проблеми виховання високо свідомого громадянина відповідає вимогам Закону України «Про освіту», Державній національній програмі «Освіта (Україна XXI століття)», «Концепції національного виховання сту- дентської молоді», «Національній доктрині розвитку освіти України у XXI столітті», Державній цільовій соціальній програмі «Молодь України» на 2016-2020 рр. [1].

Виховання толерантності у студентів ВН3, зокрема майбутніх фрахівців морського та річкового транспорту, є важливою умовою для подальшої гуманізації й демократизації суспільства. Тому проблема толерантності, яка взагалі не є принципово новою для наукової літератури, набуває сьогодні особливої актуальності.

Оновлення змісту української вищої освіти актуалізує завдання розвитку толерантності як показника деонтологічної компетентності студента, оскільки сучасні вимоги до вузівської освіти визначають пріоритетом не лише професійні якості майбутнього фахівця, але і його здатність як суб'єкта взаємодії з людьми різних соціальних, зокрема етнічних, груп [6].

Для майбутніх фахівців морського та річкового транспорту це є дуже важливим аспектом роботи. І толерантними у своїй роботі та взаємовідносинах мають бути не лише робітники вищого плавскладу, а й майбутні матроси, мотористи (машиністи), суднові електрики та інші. Тому судноплавні компанії, що несуть відповідальність за добір і підготовку моряків, дуже ретельно перевіряють майбутніх фахівців не лише на рівень спеціальних професійних знань, а і на можливість знаходити вихід із проблемних ситуацій, вирішувати нестандартні проблеми без порушення культурних і моральних принципів та традицій інших людей у колективі.

Розглянувши основні документи, що регламентують рівень професійної підготовки моряків, зокрема Конвенцію ПДНВ, можна зазначити наявність компетентнцій, що передбачають високий рівень толерантності до всіх членів екіпажу. Наприклад, у специфікації мінімальних стандартів компетентності як рівня управління, так і рівня експлуатації включено компетенції, що стосуються вміння працювати в команді, лідерства та мистецтва управління. Аналогічні компетенції включено також і в специфікації мінімальних стандартів компетентності машинної команди на рівнях експлуатації та управління.

Специфікація мінімальних стандартів компетентності постійно доповнюється. Нові компетенції пов'язані не лише з підвищенням технічного рівня спеціалістів, а також стосуються застосування навичок керівництва та вміння працювати в команді. А це неможливо без належного рівня поваги до інших членів екіпажу - як тих, що займають нижчі посади, так і тих, що мають культурні та расові відмінності.

Сьогодні українські моряки у складі екіпажів морських вантажних, пасажирських, рибальських та інших типів торгових суден працюють в усьому світі. Їхня чисельність в Україні за різними підрахунками становить від 40 до 80 тисяч осіб, і вони 
працюють переважно на суднах під іноземними прапорами, оскільки свій торговельний фрлот за час незалежності Україна майже втратила [1].

Українські морські дипломи і кваліфікаційні свідоцтва визнаються світовими морськими товариствами, що свідчить про якість змісту навчання, що забезпечувалась працею багатьох поколінь працівників системи професійної підготовки моряків. Однак рівень компетентності випускників недостатній.

За даними морських агентств із працевлаштування, менше половини підготовлених і сертифікованих українських моряків відповідають вимогам світового ринку праці. При цьому з кожного десятка українських моряків, які все-таки працевлаштувалися до судновласних компаній під «іноземним прапором», двоє-троє достроково списуються із судна на берег протягом рейсу через невідповідність вимогам судновласників $[7$, с. 67-70].

Значна доля таких моряків має достатній рівень знань, але стикаються з неможливістю психологічно комфортно працювати фрізично та перебувати на судні цілодобово в колективі, що є мультикультурним зі своїми специфічними звичками. I хоча в програмах навчання майбутніх працівників морської і річкової галузі разом із технічними дисциплінами приділяється увага вивченню соціально спрямованих дисциплін, цього не досить.

Більшість студентів не приділяє значної уваги вивченню таких дисциплін, як соціологія, політологія, етико-релігійна толерантність у багатонаціональних екіпажах та інших, нехтуючи ними. I, потрапляючи на судно, деякі 3 них просто не знають, які проблеми оточують різні спільноти з іншими релігійними та культурними особливостями, відповідно, провокують конфлікти, зачіпаючи важливі питання життя та побуту людей іншої релігійної належності.

Отже, психологічна адаптація морських фрахівців до умов здійснення професійної діяльності у складі екіпажу виявляється істотно складнішою порівняно з представниками інших професій, що зумовлено як впливом технологічної системи судна та зовнішнього середовища, так і суміщенням професійної діяльності й життєдіяльності в єдиних просторово-часових умовах[8].

Висновки і пропозиції. В умовах модернізації системи освіти України, входження її в європейський освітній простір особливої актуальності набуває проблема професійної підготовки робітників морського транспорту та формування в процесі навчання самодостатньої особистості з розвиненою індивідуальністю. Відтак нагальної потреби набуває необхідність створення в навчальному процесі таких педагогічних умов, які $б$ сприяли формуванню професійно важливих якостей майбутніх кваліфікованих робітників морського профілю. На цьому зосереджено увагу в нормативно-правових документах, що регламентують напрями розвитку освітньої діяльності в Україні: Конституції України, законах України «Про освіту», «Про професійно-технічну освіту», Національній доктрині розвитку освіти України та інших [1].

Важливим аспектом має бути постійне вдосконалення існуючих освітніх програм відповідно до міжнародних норм і стандартів. Під час оцінки професійних якостей майбутнього моряка поряд 3 його теоретичними знаннями треба приділяти більше уваги його психологічним якостям, таким як неконфліктність, уміння опановувати себе у стресових ситуаціях і вирішувати проблему без порушення інтересів інших осіб у колективі.

Отже, враховуючи важливу роль етико-релігійної толерантності в підготовці майбутніх моряків, можна виділити дві додаткові компетентності, які можна додати в перелік загальних або спеціальних в освітні стандарти спеціальності 271 «Річковий та морський транспорт»:

- здатність до соціальної толерантності в багатонаціональному екіпажі;

- здатність правильно й адекватно реагувати на релігійні чи міжособистісні конфлікти, що виникають під час роботи в змішаних екіпажах на суднах під іноземним прапором.

\section{Список використаної літератури:}

1. Черненко Н. Педагогічні умови реалізації андрагогічного підходу у професійній підготовці робітників морського транспорту : дис. ... канд. пед. наук : 13.00.04 - теорія і методика професійної освіти / Херсонська академія неперервної освіти. Херсон, 2016. 282 с. URL: https:// www.google.com/url?sa=t\&rct=j\&q=\&esrc=s\&sour ce=web\&cd =\&ved=2ahUKEwipt66V3MfpAhXJtYs KHaiOBXoQFjABegQIAhAB\&url=http $\% 3 A \% 2 F \% 2$ Fwww.kspu.edu\%2FFileDownload.ashx\%2FDiss_ Chernenro.pdf\%3Fid\%3D8b71e90a-d511-404e$94 \mathrm{~b} 6 \mathrm{f} 2 \mathrm{c} 3 \mathrm{dd} 2281 \mathrm{~b} 8$ \& u s g = A O v Vaw $3 \mathrm{~m}$ 5RCNXonFp80sm_9vwlvQ (дата звернення: 01.05.2020).

2. Жданова І. Молодь і толерантність в сучасній Україні (національно-етнічний аспект): Агора. Перспективи соціального розвитку регіонів. Київ, 2008. Вип. 7. С. 25-35.

3. Гнатчук О. Формування толерантності студентської молоді на принципах релігійних цінностей. URL: http://www.sociology.chnu.edu.ua/res// sociology/Chasopys/Vup1(7)/16.pdf (дата звернення: 01.05.2020).

4. Правові засади захисту особистісних цінностей та суспільної моралі : збірник нормативних актів України / уклад. : Ю. Шайгородський, К. Меркотан. Київ : Український центр політичного менеджменту, 2007. 440 с. 
5. Орловська О. Толерантність та її сутнісні характеристики. URL: http://www.irbis-nbuv.gov.ua/cgibin/ irbis_nbuv/cgiirbis_64.exe?C21COM=I21DBN $=U J R N \& P 21 D B N=U J R N \& \% 0 B I M A G E \_F I L E$ DOWNLOAD $=1 \&$ Image_file_name $=P D F /$ Znpkhist_2012_5_37.pdf (дата звернення: 01.05.2020).

6. Вайнола Р., Чжан С. Формування етнічної толерантності студентської молоді в системі виховної роботи вищого навчального закладу. URL: http://dspu.edu.ua/hsci/wp-content/uploads/2017/ 11/015-34.pdf (дата звернення: 04.05.2020).
7. Підпала І. Правові вимоги до кандидатів у члени морського екіпажу за нормами міжнародного та національного законодавства. Вісник Київського національного університету. Юридичні науки. Київ : КНУ, 2011. Вип. 88. С. 67-70.

8. Шерман М. Дослідження впливу особливостей морської праці на толерантність моряків міжнародних екіпажів. Молодий вчений. 2016. № 3. C. 450-454. URL: http://nbuv.gov.ua/ UJRN/molv_2016_3_108 (дата звернення: 06.05.2020).

Shaikhatdinov A., Dobina T. The role of ethical and religious tolerance in the formation of professional competencies of future specialists of sea and river transport

The article deals to the study of the role of ethical and religious tolerance in the formation of professional competencies of future specialists in sea and river transport. The theoretical foundations of ethical and religious tolerance and the multidimensionality of the term tolerance are considered. The existing types of tolerance and the basic principles of tolerance are analyzed in accordance with the declaration of the principles of tolerance approved by the UN General Conference. Tolerance is unity in diversity. Tolerance is not only a moral duty, but also a political and legal need. Tolerance is what makes peace possible, facilitates the transition from war to a culture of peace.

Updating the content of Ukrainian higher education actualizes the task of developing tolerance as an indicator of the deontological competence of a future specialist in sea and river transport. It has been proven that the International Convention on STCWS contains competencies providing a high level of tolerance to all crew members. For example, competencies related to teamwork, leadership and management skills. Today, Ukrainian sailors as part of the crews of sea cargo, passenger, fishing and other types of merchant ships operate all over the world. Since these vessels have multinational mixed crews, it is impossible to work without the proper level of both technical training and tolerance for others. The study revealed that the competencies for specialists in sea and river transport are constantly being supplemented and enhanced. As a result of the study, it was proposed to add such competencies to the list of general or special educational standards of the specialty: the ability to social tolerance in a multinational crew and the ability to correctly and adequately respond to religious or interpersonal conflicts that arise while working in mixed crews on ships flying a foreign flag.

Key words: ethical and religious tolerance, professional competencies, maritime industry, International Convention on STCWS, declaration of principles of tolerance, psychological adaptation of sailors. 